\title{
Residual flow over a bump in Quellón Bay
}

\author{
Flujo residual sobre un promontorio submarino en bahía Quellón \\ Mario Cáceres ${ }^{1 *}$, Arnoldo Valle-Levinson ${ }^{2}$ and Mónica Bello ${ }^{3}$ \\ ${ }^{1}$ Facultad de Ciencias del Mar y de Recursos Naturales, Universidad de Valparaíso, Valparaíso, Chile \\ Casilla 5080 Reñaca, Viña del Mar, Chile \\ ${ }^{2}$ Civil and Coastal Engineering Department, University of Florida, Gainesville, FL 32611, U.S.A. \\ ${ }^{3}$ Servicio Hidrográfico y Oceanográfico de la Armada, Errázuriz 232, Valparaíso, Chile \\ mario.caceres@uv.cl
}

Resumen.- Se realizaron mediciones de velocidad y perfiles de densidad del agua de mar para describir la estructura del

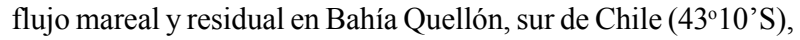
una bahía abierta hacia el este cuya boca es de ca. $6 \mathrm{~km}$ (nortesur) y en cuya cabeza se ubica un río de baja descarga asociado a un humedal de alta productividad. Se obtuvieron perfiles de corrientes durante invierno y primavera con un Perfilador Acústico de Corrientes Doppler (ADCP) de $307.2 \mathrm{kHz}$, a lo largo de un circuito triangular repetido durante dos ciclos de marea semidiurna. El lado este del triángulo consistió en un transecto orientado en dirección norte-sur que cruzaba a lo ancho de la boca de la bahía; los otros dos lados se orientaron aproximadamente en la dirección este-oeste a lo largo de la bahía, denominándose transectos norte y sur. El triángulo se ubicó sobre un pequeño promontorio submarino de ca. $10 \mathrm{~m}$ de profundidad, rodeado por batimetría de alrededor de 20 a $30 \mathrm{~m}$. Se realizaron perfiles de densidad en el vértice oeste del triángulo. El flujo residual longitudinal en el transecto este, en el sector de la boca, mostró un intercambio lateral que consistió en flujo de entrada (hacia el oeste) por el lado norte de la bahía y flujo de salida (hacia el sureste) por el lado sur. El flujo lateral residual mostró aumentos en la magnitud de la componente hacia el sur que estarían relacionados con la presencia del promontorio submarino. El flujo residual longitudinal fue principalmente hacia el oeste en el lado norte y hacia el este en el lado sur, sugiriendo que el flujo entra a la bahía por el norte y sale por el sur. En el transecto sur hubo evidencias de divergencia del flujo sobre el promontorio, la cual promueve velocidades verticales positivas sobre este rasgo batimétrico. La velocidades hacia arriba sobre el promontorio y hacia abajo sobre el flanco hacia el este se estimaron usando la ecuación de continuidad sobre una grilla regular. Hubo evidencias de que la divergencia es inducida por separación del flujo generada por un par de vórtices rotando en sentido encontrado sobre este rasgo batimétrico. Los términos no lineales de la ecuación de movimiento parecen dominar el balance dinámico. La variabilidad intra mareal del flujo y la densidad en la estación repetida no mostró diferencias significativas entre la estación lluviosa y la menos lluviosa, sugiriendo que la dinámica del sistema es menos afectada por la descarga de río. Pequeños aumentos de salinidad se asociaron al efecto de la fase de la marea. No hubo diferencias significativas entre los muestreos de julio y noviembre ni en los patrones del flujo residual ni en el campo de densidad.

Palabras clave: ADCP, vorticidad, divergencia, Chile, fiordo
Abstract.- Measurements of velocity and density profiles were used to describe the tidal and residual flow structure in Quellón Bay, southern Chile (4310'S), an eastward opened bay with $c a .6 \mathrm{~km}$ width (north-south) at its mouth and a low river discharge at its head, associated to a productive marshlike branch. Current profiles were obtained in winter and spring with a $307.2 \mathrm{kHz}$ Acoustic Doppler Current Profiler (ADCP) during two semidiurnal cycles along a repeated triangular circuit. The eastern side of the triangle consisted in an acrossbay transect oriented in the north-south direction, and two along-bay (aprox. east-west oriented) transects formed the other sides identified as northern and southern transects. The triangle circumscribed a small bump of $c a .10$ depth, surrounded by bathymetry of the order of 20-30 m. Density profiles were obtained at the westernmost corner of the triangle. The longitudinal mean flow in the eastern transect at the mouth showed a lateral exchange structure that consisted in inflow (westward) over the northern side and outflow (southeastward) over the southern side. Lateral residual flow showed increases of the southward component that seems to be related to the presence of the bump. The longitudinal residual flow was mostly westward in the southern transect and eastward in the southern transect, suggesting that flow enters the bay through the northern side and exits through the southern side. Over the southern transect there were evidences of flow divergence over the bump which promotes upward velocities over this feature. Upward velocities over the bump and downward velocities over the eastern flank were estimated using the continuity equation. There were evidences that divergence is induced by flow separation yielded by a pair of counter-rotating vortex over this feature. Nonlinearities seem to dominate the tidal dynamic balance. The intra tidal variability of flow and density at the repeated station showed no significant differences between the low and high rainy seasons, suggesting that dynamics of the system is less affected by river discharge. Small increases of salinity were associated to the effect of tidal flood phase. There were no significant differences between samplings on July and November, nor in residual flow patterns or in density field.

Key words: ADCP, vorticity, divergence, Chile, fjords

\footnotetext{
* Invited author
} 


\section{Introduction}

The interaction of flow with bathymetric features can introduce significant modifications to the residual flow observed in estuarine systems. These disturbances may include, residual vorticity by column stretching and squashing (Robinson 1983, Park \& Wang 1994), increases in importance of nonlinear advection in dynamic balance (Valle \& Atkinson 1999, Cáceres et al. 2003), generation of lee waves (Dewey et al. 2005) and upwelling over bathymetric features like bumps (Tee \& Smith 1993), among others.

For the purposes of this work, the term 'residual current' is defined here as that part of the current that is left after removal of the diurnal and semidiurnal signals. In estuarine systems, tide induced currents include the oscillating currents of various tidal constituents and, through nonlinear interactions, the oscillating components of shallow-water constituents and the residual circulation.

The present work explores the residual tidal and transient circulation in Quellón Bay, southern Chile. This bay has an east-west orientation, eastward opened, and is ca. $6 \mathrm{~km}$ long (E-W) and $5 \mathrm{~km}$ wide $(\mathrm{N}-\mathrm{S})$ at its mouth. Width decreases to the west to form a shallow and narrow northward channel at its head (Yaldad estuary), where the short Yaldad river (30 km long) provides the only source of fresh water to the bay. Coldita channel, the southern branch at the head, may considered be closed to the flow coming from the south, as there is a very shallow barrier not allowing for navigation of small boats. A notable bathymetric feature of this bay is a bump of $c a$. $10 \mathrm{~m}$ deep on its center.

Yaldad estuary, the northern branch, is a shallow marsh-like system where intensive activities of fish and mytilids farmings are developed. It provides one of the main sources of incomes for local fishermen in the area. There is no data available on freshwater discharge for Yaldad river, but it seems to be very low, as discharges of close rivers sharing the same hydrographic basin has been reported to be in the order or 1 to $8 \mathrm{~m}^{3} \mathrm{~s}^{-1}$ (Niemeyer \& Cereceda 1984). The eastern side of Chiloé Island has a chain of low hills oriented in the north-south direction, located so near of the eastern coastline, which makes most of the rivers on this side having low discharges because of their shortness and gentle slopes. Climate regime of the area is rainy and temperate. Historical monthly mean precipitation data at Quellón station show the lowest value (72 $\mathrm{mm}$ ) occurring in February (summer) and the highest value $(226 \mathrm{~mm})$ occurring in July (winter), following a typical seasonal oscillation of rainy increases in winter (data from Chilean National Direction of Water
Resources, DGA). These are also similar values for other stations in eastern Chiloé Island, but they might be duplicated on stations in the continental margin of the Chilean Inland Sea at similar latitudes. According to nautical chart number 7440 of Hydrographic and Oceanographic Service of Chilean Navy (SHOA), maximum tidal ranges during spring tides in Puerto Quellón are about $5 \mathrm{~m}$. Typical tidal currents eastward of Puerto Quellón are about 0,5 to $2 \mathrm{~m} \mathrm{~s}^{-1}$.

This work describes for the first time the distribution of residual velocities in Quellón Bay in two seasonal experiments using towed ADCP measurements, and assesses the importance of bathymetry on the circulation patterns in the bay.

\section{Material and methods}

\section{Data collection and processing}

The objectives of this work were pursued in Quellón Bay $\left(43^{\circ} 10^{\prime} \mathrm{S}, 73^{\circ} 42^{\prime} \mathrm{W}\right)$ (Fig. 1), and they were addressed with measurements of underway velocity profiles and fixed profiles of temperature and salinity.

Underway velocity profiles were obtained with a broadband 307.2 KHz RD-Instruments Acoustic Doppler Current Profiler (ADCP) along 3 transects depicted in triangular form: 1) northern (A-B), 2) eastern (B-C), and 3) southern (C-A) (Fig. 1), which were sampled repeatedly 15 times during 24 hours on July $20^{\text {th }}$ and on November $14^{\text {th }}, 2005$. Both dates corresponded to one day before spring tides. This generated time series of 15 points at each (longitude, latitude, depth) position of the survey. The ADCP was towed on a $3 \mathrm{~m}$-long catamaran along the starboard side of the R/V AGOR 'Vidal Gormaz' at speeds between 2.0 and $2.5 \mathrm{~m} \mathrm{~s}^{-1}$. Velocity profiles with a vertical resolution of $1 \mathrm{~m}$ and ping rates of $\sim 1 \mathrm{~Hz}$ were averaged every $30 \mathrm{~s}$, yielding a spatial resolution of $60-75 \mathrm{~m}$. A Global Positioning System (GPS) Leica was interfaced to a laptop to record data position. The ADCP compass was calibrated using GPS navigation data following Trump \& Marmorino (1997). Water density, temperature and salinity profiles were measured repeatedly in point $A$ of the triangle (Fig. 1) with a Seabird 19 CTD (Conductivity, Temperature and Depth) instrument. Meteorological data were recorded in intervals of 15 minutes on board of research vessel.

Bad ADCP data were removed using the following criteria: all measurements within $10 \%$ of the bottom were discarded due to side lobe-effects; velocity measurements with absolute error velocities (calculated as the difference between vertical velocity measurements by independent beams) $>8 \mathrm{~cm} \mathrm{~s}^{-1}$ (about $4 \%$ of maximum flows in the 


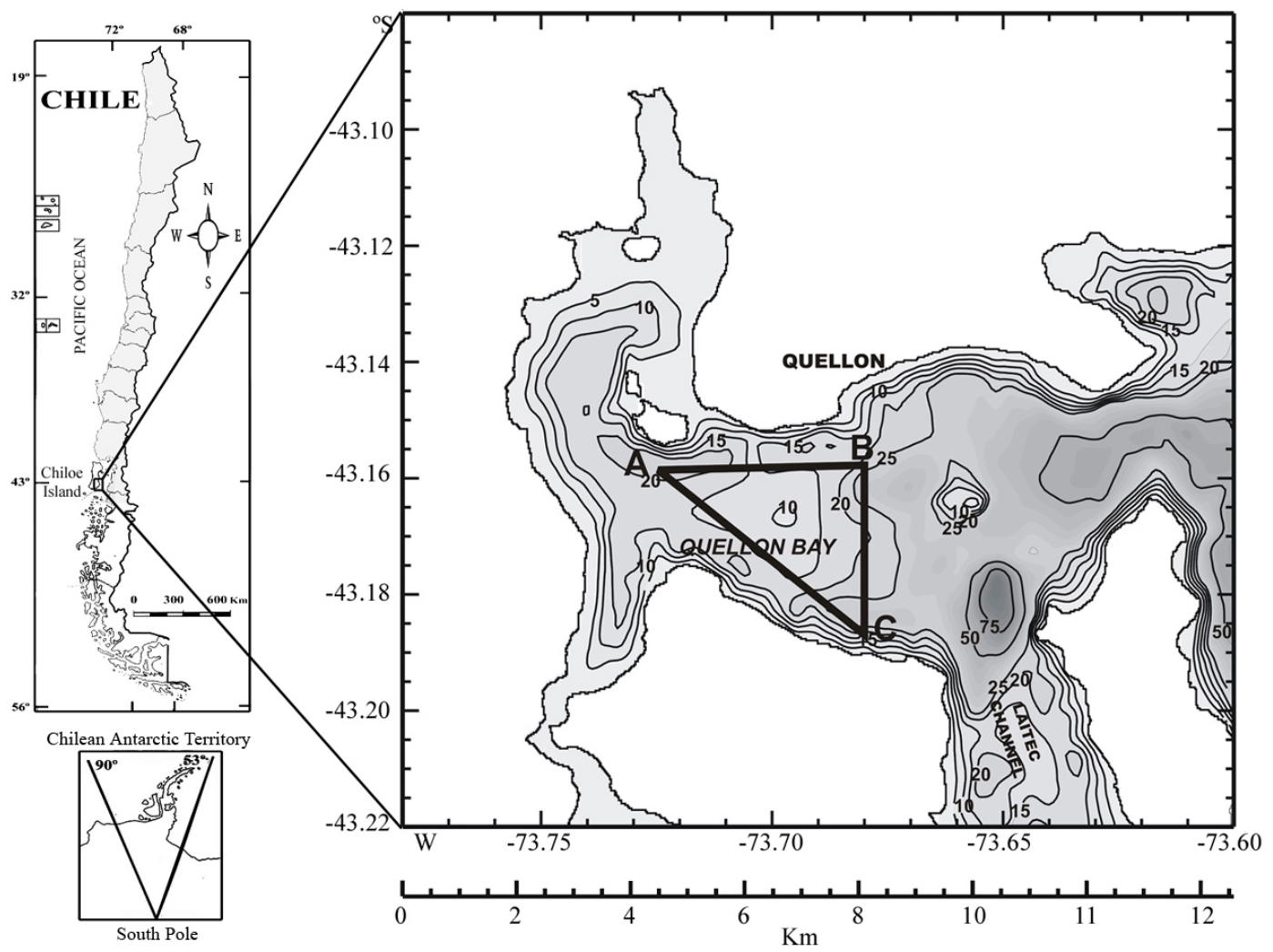

Figure 1

Study area and position of ADCP transects in Quellón Bay

Área de estudio y posición de los transectos de ADCP en Bahía Quellón

area) were discarded; and any data point with a signal return of $<90 \%$ good was also discarded. A correction of the remaining data for compass errors and velocity magnitude errors was then carried out according to Trump \& Marmorino (1997), as explained in more detail by ValleLevinson \& Atkinson (1999). After the heading correction was applied, the data were rotated counterclockwise to an along- ( $u$ flow) and across- ( $v$ - flow) bay coordinate system. These angles were oriented in the direction of greatest variability of the tidal currents and of weakest across-channel tidal flows. After that, the data were interpolated onto uniform distance-depth grids. Each grid point of each of the 3 transects had time series of 15 values for $u, v$, and time. Semidiurnal and diurnal constituents, represented by $\mathrm{M}_{2}$ and $\mathrm{K}_{1}$ respectively, were then separated from the subtidal signal of the observed flow components at each grid point. The remaining signal constituted the residual flow. The separation of signals was made with a sinusoidal least-squares regression analysis applied to time series of 15 points (e.g. Lwiza et al. 1991). The least squares fit with both constituents consistently explained $>65 \%$ (mean of $78 \%$ ) and $>65 \%$ (mean of $80 \%$ ) of the variability observed in the longitudinal component of western and eastern transects, respectively. The root-mean-squared ( $\mathrm{rms}$ ) errors of the least squares fits had a mean of $0.08 \mathrm{~m} \mathrm{~s}^{-1}$ for both transects.

\section{Results}

The motivation of the present study was to understand the flow variability in the region of exchanges of Quellón Bay with the adjacent basin, to estimate the importance of bathymetry in determining flow patterns, and to assess seasonal changes associated with river discharge coming from the west.

Residual currents in transect 2 represented by velocity contours of the east-west $u$-component are shown in Fig. 2. The classical pattern of an estuarine two layer exchange is just slightly suggested from the vertical distributions of velocities. July sampling shows that eastward (outflows) near surface are almost absent, and November sampling shows 

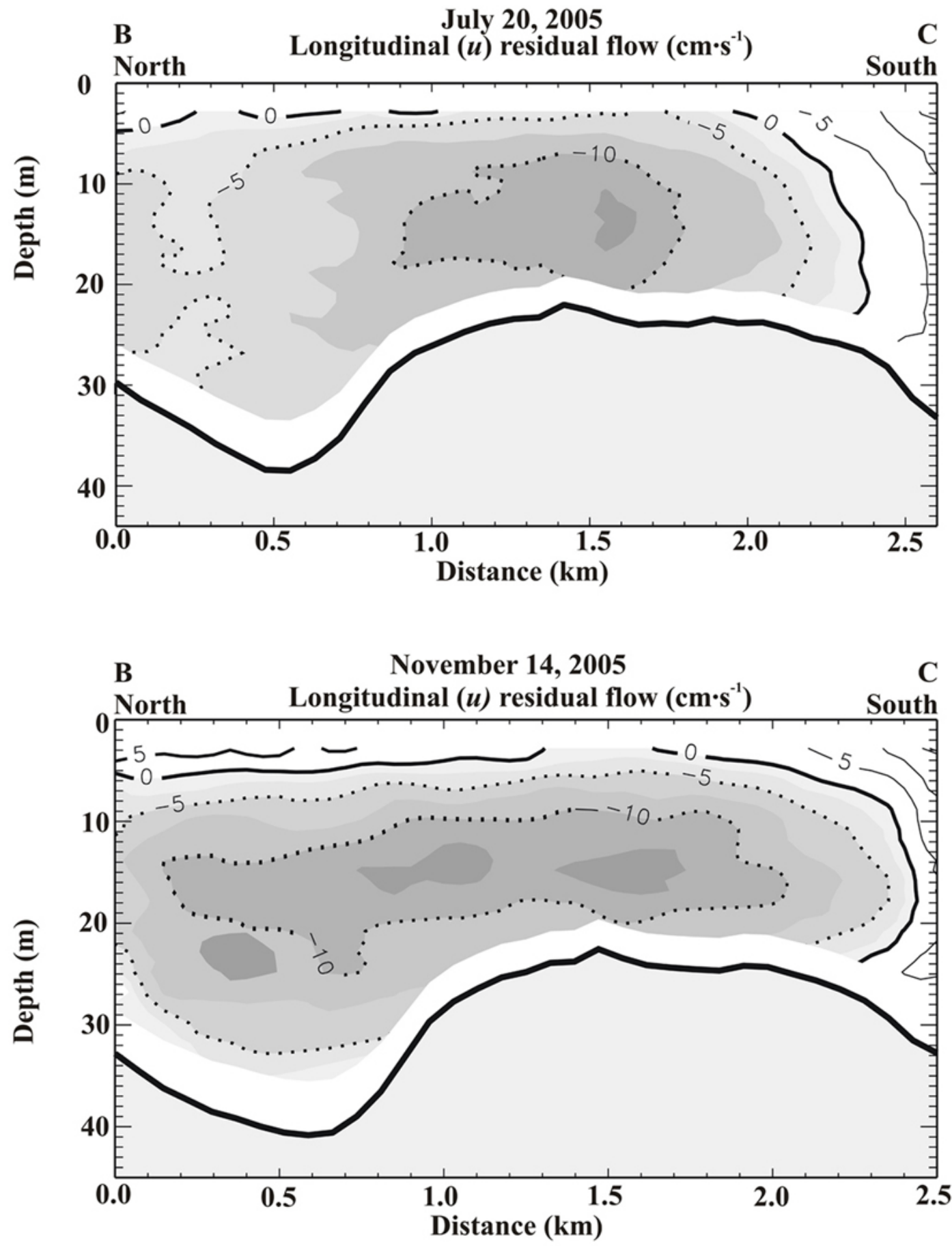

Figure 2

Residual velocity contours $\left(\mathrm{cm} \mathrm{s}^{-1}\right)$ of the longitudinal $(u)$ component in transect 2 . Positive (white, solid lines) is eastward and negative (gray tones, dotted lines) is westward. Looking eastward. White region close to bottom profile is bad data due to lobe side effect of ADCP and is not considered in the analysis

Contornos de velocidad residual $\left(\mathrm{cm} \mathrm{s}^{-1}\right)$ de la componente longitudinal $(u)$ en el transecto 2. Valor positivo (blanco, línea sólida) es hacia el este y negativo (grises, línea punteada) es hacia el oeste. Orientación mirando hacia el este. La región blanca cercana al fondo corresponde a datos de baja calidad debida al efecto de interacción lateral de los lóbulos del 

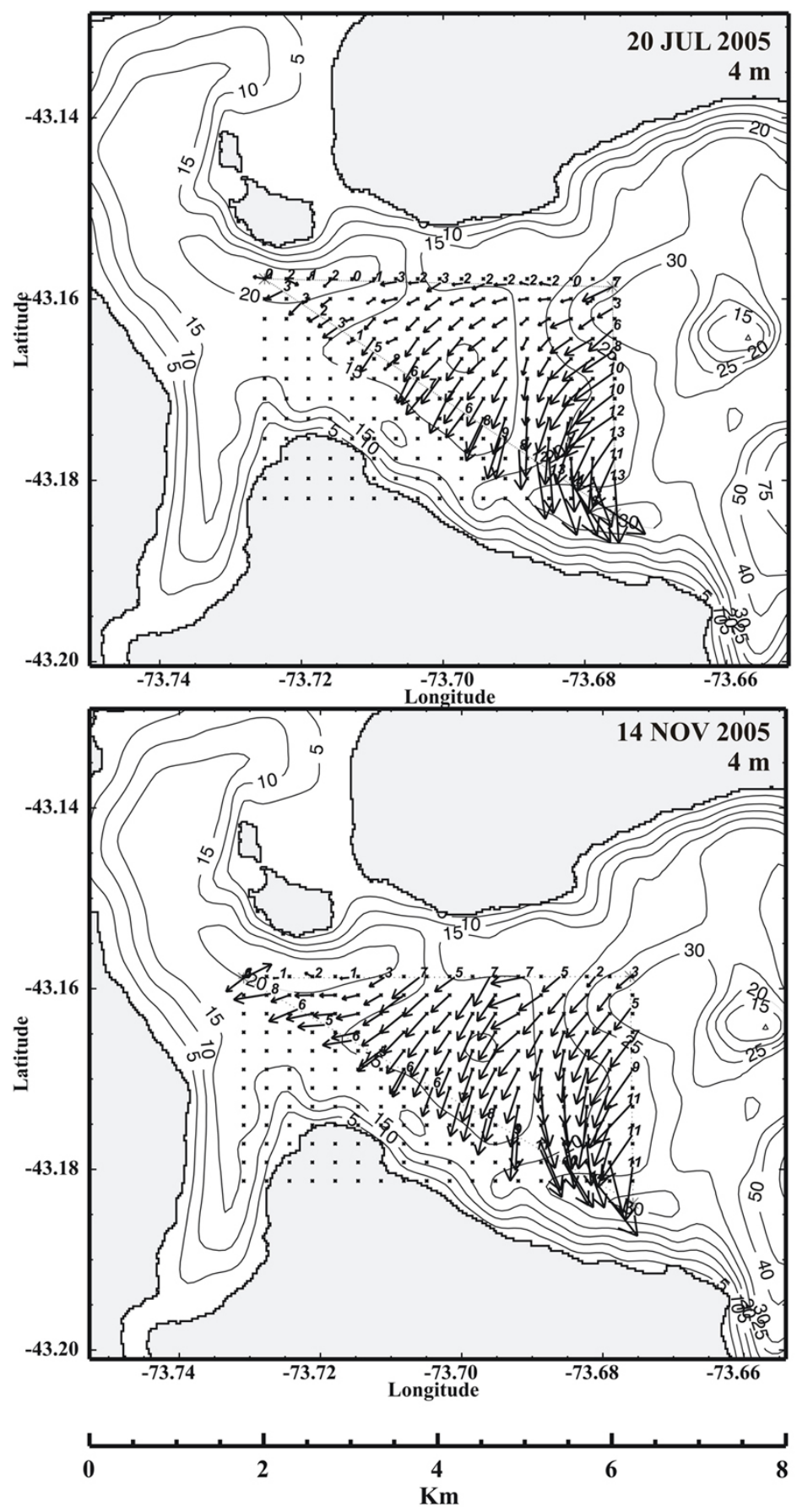

Figure 3

Residual velocity vectors at $\mathbf{4} \mathbf{m}$ depth. Arrows over sides of triangle are calculated and those inside of triangle are interpolated in a regular grid. Grid points out of the triangle are out of the analysis. Numbers at the base of arrows on sides of triangle are velocity magnitudes $\left(\mathrm{cm} \mathrm{s}^{-1}\right)$ for reference

Vectores de velocidad residual a $4 \mathrm{~m}$ de profundidad. Las flechas sobre los lados del triángulo son valores calculados y los del interior del triángulo son interpolados en una grilla regular a partir de los valores calculados. Los puntos fuera del triángulo han sido eliminados del análisis. Los números en la base de las flechas sobre los lados del triángulo con magnitudes de la velocidad $\left(\mathrm{cm} \mathrm{s}^{-1}\right)$ para referencia 

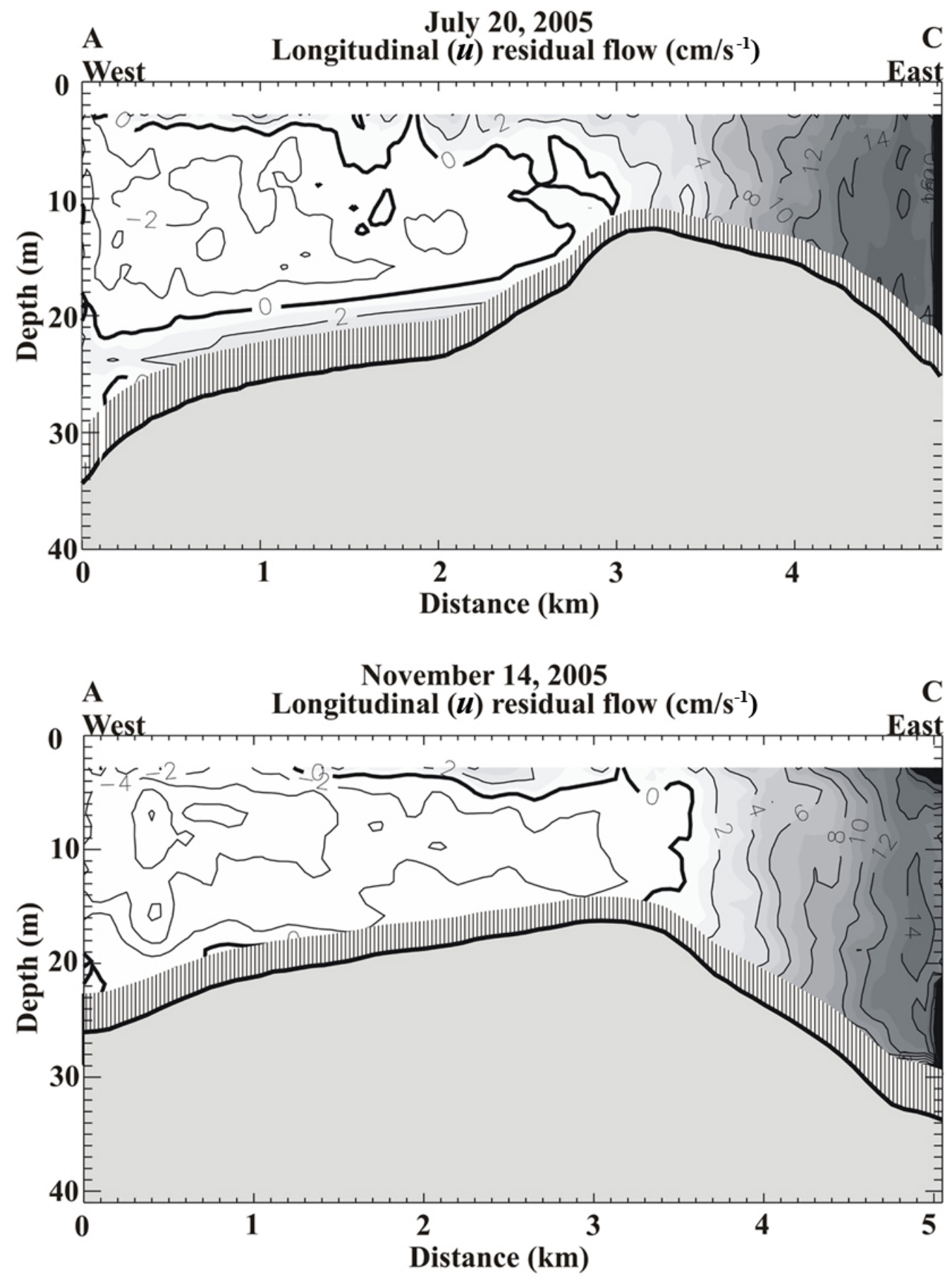

Figure 4

Residual velocity contours $\left(\mathrm{cm} \mathrm{s}^{-1}\right)$ of the longitudinal $(u)$ component in transect 3. Positive (gray tones) is southeastward and negative (white) is northwestward. Looking northeastward. Dashed region close to bottom profile is bad data due to lobe side effect of ADCP and is not considered in the analysis

Contornos de velocidad residual $\left(\mathrm{cm} \mathrm{s}^{-1}\right)$ de la componente longitudinal $(u)$ en el transecto 3 . Valor positivo (tonos grises) es hacia el sureste y negativo (blancos) es hacia el noroeste. Orientación mirando hacia el noreste. La región achurada cercana al fondo corresponde a datos de baja calidad debida al efecto de interacción lateral de los lóbulos del 

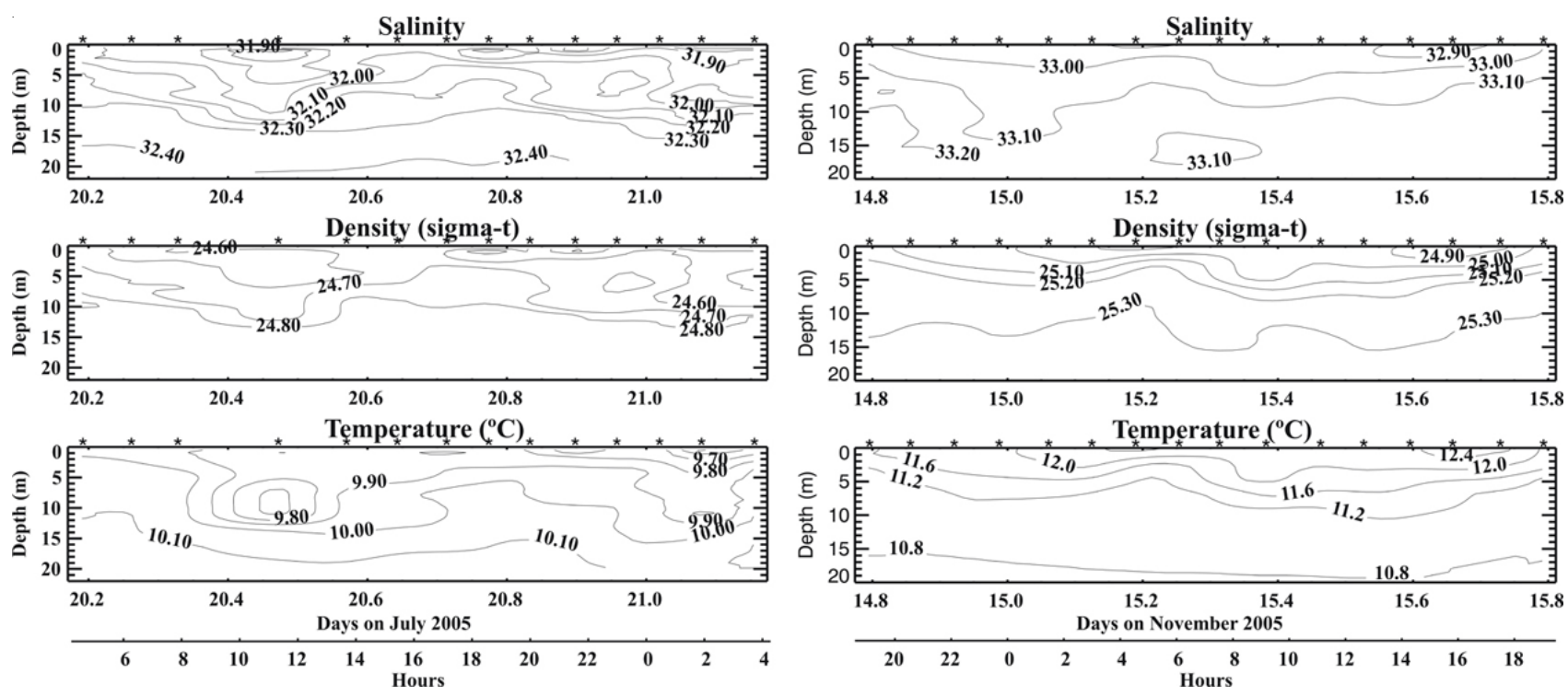

Figure 5

Temperature, salinity and density at station A, during winter (July 20) and spring times (November 14, 2005). Asterisks over horizontal upper axis are times of CTD casts

Temperatura, salinidad y densidad en la estación A durante el invierno (20 de julio) y la primavera (14 de noviembre, 2005). Los asteriscos sobre el eje horizontal superior corresponden a la ejecución de las estaciones de CTD

evidence of positive (outflows) velocities in a thin layer of about $4 \mathrm{~m}$ depth near surface. A lateral pattern is a more distinct feature evident in velocity distributions, as transverse variability suggests inflow (westward, negative values) through the northern side, and outflow (eastward, positive values) through the southern side. This pattern is also observed in vectorial representation of currents at surface (Fig. 3). Here, the interior of triangle has been linearly interpolated from calculated values of the sides, in a regular grid of $250 \mathrm{~m}$ intervals in the north-south $(d y)$ and esat-west $(d x)$ dimensions. As suggested in velocity contours (Fig. 2), flow seems to enter the bay through the northern region and exits through the southern region suggesting a tendency to rotate counterclockwise on the eastern side of the bump and clockwise on the western its western side.

Therefore, flow separation in two branches over bump is observed, which potentially promotes divergence over this feature. Evidence of divergence is suggested in Fig. 4 , which shows vertical contours of the along-transect (u) component, where flow is roughly divided in a northwestward part and a southeastward part.

The largest magnitudes $\left(c a .19 \mathrm{~cm} \mathrm{~s}^{-1}\right)$ of residual currents were observed on outflow in the southern side. There was a tendency for currents to enter through Canal Laitec, suggesting that waters of the bay are exported to the south.
A weak evidence of a two-layer system was also suggested by vertical temporal distributions of salinity during $24 \mathrm{~h}$ samplings in station A (Fig. 5). Salinity remains higher than 31 throughout the whole water column suggesting low effect of river discharge in the surface layer, as evidenced by small decreases each $12 \mathrm{~h}$ in surface temperature $\left(<0.4^{\circ} \mathrm{C}\right)$ and salinity $(<0.2)$ in both months. This pattern suggests that the system exhibits a low river discharge and weak stratification. Wind observations revealed calm conditions ( $<5$ knots wind magnitude) during collection data on both campaigns.

\section{Discussion}

The main characteristics of residual flow are now analyzed in the context of the bump effect on the dynamic balance, as a mechanism of tidal vorticity, and as a place of flow divergence.

The effect of bathymetry over patterns of residual flow in the across-estuary dimension has been explained by $\mathrm{Li}$ \& O'Donnell (1997) and Valle \& Atkinson (1999) as the result of tidal rectification by bathymetry. Their results show that inflows concentrate over shoals and outflows over channels, as observed by Cáceres et al. (2003) in an energetic tidal channel with a prominent bank on its center.

In order to explore the effects of the nonlinear terms on the tidal momentum balance, we estimated mean values 
of $<\partial v / \partial y>$ or $<\partial u / \partial x>$ in residual flows for each transect these experiments, where brackets $<>$ are averages of the time sampling. Choices of $\langle\partial v \partial y\rangle$ or $\langle\partial u \partial x>$ were made according to the orientation of transects, considering that we could reliably solve with measurements available. Therefore, $<\partial u \partial x>$ was estimated for transects 1 and 3 (roughly east-west oriented), and $\langle\partial v / \partial y>$ for transect 2 (north-south oriented). Afterward, we estimated the absolute values of the mean ratios of $\langle u \partial u \partial x\rangle \mid\langle f v\rangle$ (transects 1 and 3) and $\langle\nu \partial \nu / \partial y\rangle \mid\langle f u>$ (transect 2) to explore the importance of nonlinearities over Coriolis effect. These are the only two terms that could be reliably determined in the subtidal momentum balance. Results of the mean values for these terms are shown in Table 1. It shows particularly large values of $\langle\partial \nu \partial y\rangle$ in the order of $10^{-3}$ to $10^{-4} \mathrm{~s}^{-1}$ on transect 2 , which seems to be determining the large dominance of nonlinear accelerations over Coriolis terms in more than two orders of magnitude. This is the transect with the largest magnitudes of residual flows and high vorticity, as we will see in the next section. Nonlienarities dominate over Coriolis term into the three transects.

Using a vertically integrated model, Park \& Wang (1994) examined the residual transport vorticity of tidal flow over a bump. They found an anticyclonic residual vorticity at the center and two smaller cyclonic residual transport voticities at the perimeter of the bump. In this work, residual velocities distribution suggests generation of counter-clockwise vortex over the eastern flank and clockwise vorticity about the center of the bump. Although we did not capture the full spatial extension of the bump with current measurements, and sampling design did not cover properly the center of this bathymetric feature, our results suggest that model results fairly approximate to field data on the portion of bump examined. In order to examine the effect of vorticity on patterns velocities, we evaluated relative vorticity (eq. 1) to the points of a regular grid of $u$ and $v$ components of residual flow, similar to that shown in Fig. 3, but using $400 \mathrm{~m}$ intervals in the north-south $(d y)$ and esat-west $(d x)$ dimensions.

$$
\zeta=\frac{\partial v}{\partial x}-\frac{\partial u}{\partial y}
$$

Results are shown in Fig. 6. Positive vorticity (counterclockwise) dominate on the eastern flank of the bump, and negative vorticity (clockwise) dominates on the western flank, as suggested by residual vectors in Fig. 3.

This pair of counter-rotating vortex might be inducing flow separation over the bump, and there are evidences showed in figure 4 that this bifurcation might be inducing vertical residual velocities in a region of divergence. In order to identify regions of divergence and convergence into the regular grid presented in Fig. 6, vertical velocities were estimated using the continuity equation (2), where $u$ and $v$ denotes eastward and northward vertically averaged residual velocities, respectively. Vertical velocities $w$ were positive upward and assessed at each point of the regular grid using equation (3), where $h$ was the maximum depth on each grid point.

$$
\begin{gathered}
\frac{\partial u}{\partial x}+\frac{\partial v}{\partial y}+\frac{\partial w}{\partial z}=0 \\
w=\left.\frac{\partial w}{\partial z} z\right|_{0} ^{h}
\end{gathered}
$$

Vertical velocities are shown in Fig. 7. On both seasonal legs, positive values (upward velocities) are concentrated over the bump, and negative (downward velocities) are mostly observed over the flanks. Largest values are mostly located on the eastern flank of the bump.

Table 1

\section{Mean values of horizontal residual shears and ratios of advective to Coriolis terms on each transect}

Valores promedio de cizalles residuales horizontales y proporciones de los términos advectivos sobre el término de Coriolis en cada transecto

\begin{tabular}{lcccc}
\hline & $\langle\partial v / \partial y\rangle\left(s^{-1}\right)$ & $\left\langle\partial u / \partial x>\left(s^{-1}\right)\right.$ & $\langle v \partial v / \partial y\rangle \mid\langle f u\rangle$ & $\langle u \partial u / \partial x\rangle /\langle f v\rangle$ \\
\hline Transect 1 July & & $-3.19 \times 10^{-6}$ & & 12.19 \\
Transect 1 November & & $-1.89 \times 10^{-5}$ & & 5.65 \\
Transect 2 July & 0.0026 & & 472.3 & \\
Transect 2 November & -0.00098 & & 857.5 & \\
Transect 3 July & & $6.23 \times 10^{-5}$ & & 34.33 \\
Transect 3 November & & $-3.94 \times 10^{-5}$ & & 6.02 \\
\hline
\end{tabular}



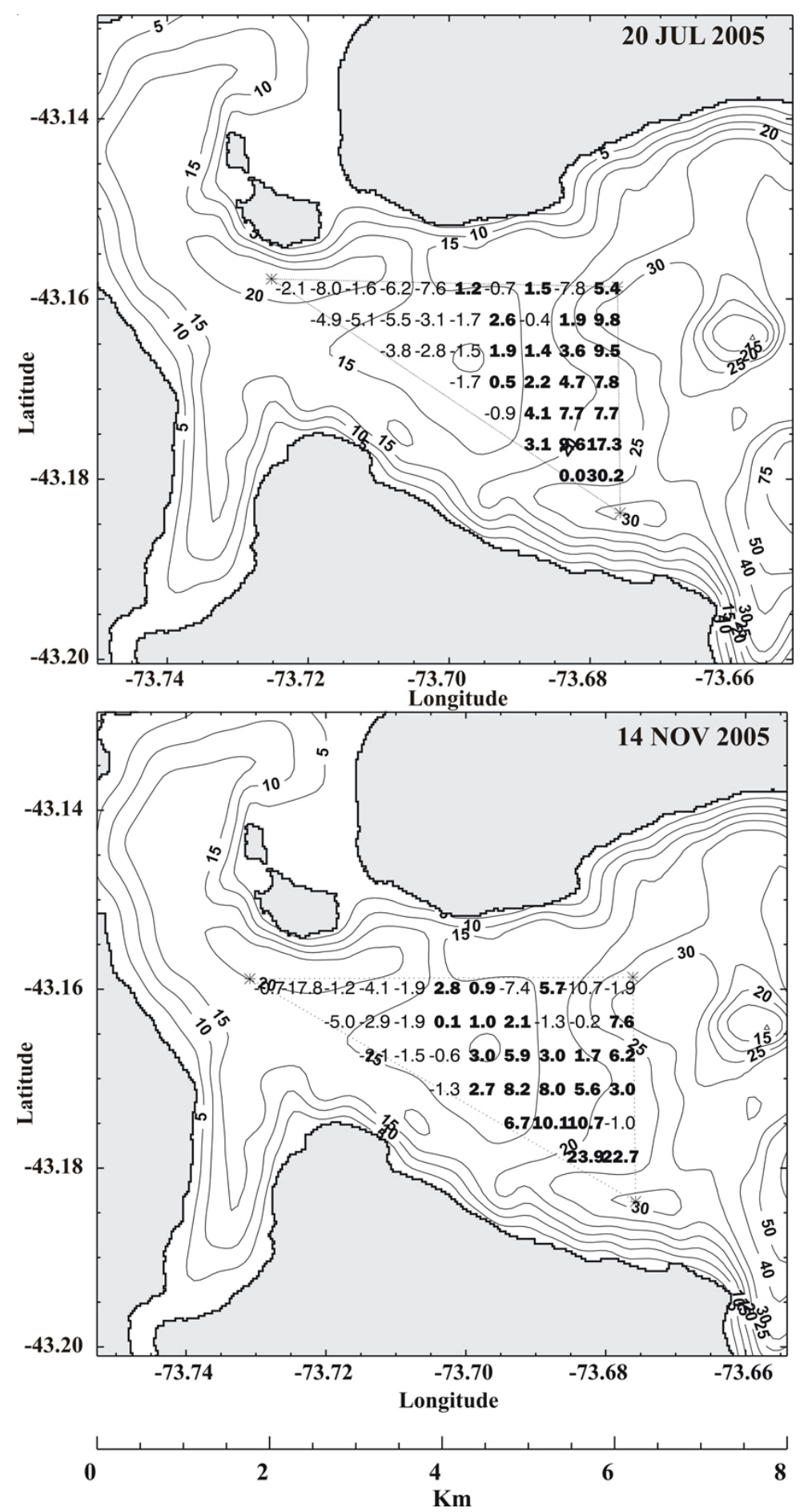

Figure 6

Residual relative vorticity $\left(\mathrm{x} \mathrm{10}^{-4} \mathrm{~s}^{-1}\right)$ interpolated in a regular grid over the triangular sampling design. Bold (positive) numbers are positive vorticity and regular (negative) are negative vorticity. Upper panel is winter time and lower panel is spring time.

Grid points out of the triangle have been removed from the figure for an easier analysis

Vorticidad relativa residual (x 10-4 s ${ }^{-1}$ ) interpolada en una grilla regular sobre el diseño de muestreo triangular. Números en negrita (positivos) corresponden a vorticidad positiva y números sin negrita (negativos) son vorticidad negativa. El panel superior es invierno y el inferior es primavera. Los puntos de la grilla fuera del triángulo han sido removidos de la figura para facilitar el análisis 

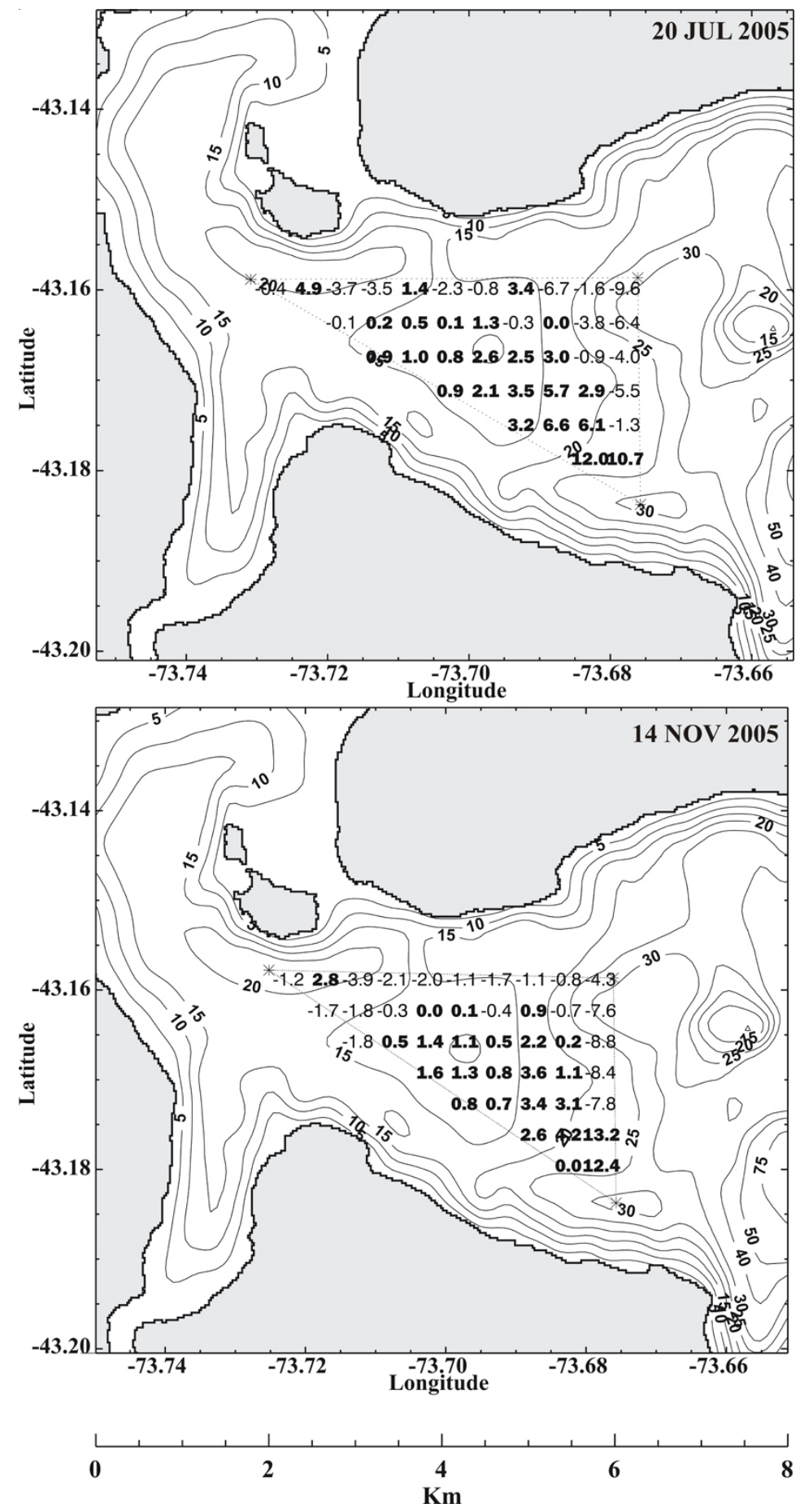

Figure 7

Vertical velocities $\left(x^{-5} \mathbf{m ~ s}^{-1}\right)$ from continuity equation interpolated in a regular grid over the triangular sampling design. Bold (positive) numbers are upward and regular (negative) are downward. Upper panel is winter time and lower panel is spring time. Grid points out of the triangle have been removed from the figure for an easier analysis

Velocidades verticales $\left(\times 10^{-5} \mathrm{~m} \mathrm{~s}^{-1}\right)$ a partir de la ecuación de continuidad interpolados en una grilla regular sobre el diseño triangular de muestreo. Números en negrita (positivos) corresponden a velocidad hacia arriba y números sin negrita (negativos) son velocidades hacia abajo. El panel superior es invierno y el inferior es primavera. Los puntos de la grilla fuera del triángulo han sido removidos de la figura para facilitar el análisis 
This figure shows evidence of divergence occurring over this bathymetric feature, which is suggested to be a mechanism for promoting vertical mixing into the bay. Regions of divergence over the bump and convergence over the flanks have been also observed in numerical solutions (Tee \& Smith 1993) in other geographical regions.

In summary, there were no significant differences between both seasons in residual flow patterns and instratidal density distributions. The subtidal dynamic balance seems to be strongly affected by nonlinearities induced by the bump, which would be the result of enhanced vorticity and divergence over this feature. Upward vertical velocities were induced by the bump suggesting an important role of this feature in maintaining permanent mixing into the bay.

\section{Acknowledgments}

We thank Jenny Maturana and Paz Pantoja for their support in instrument operation onboard. Authors also thank to officers and crew of AGOR 'Vidal Gormaz' for supporting CTD and ADCP data acquisition. Funding was provided by National Oceanographic Committee under project Cimar 11 Fiordos CONA-CF11 05-04.

\section{Literature cited}

Cáceres M, A Valle-Levinson \& L Atkinson. 2003.

Observations of cross-channel structure of flow in an energetic tidal channel. Journal of Geophysical Research 108(C4): 11-1-11-10.

Dewey R, D Richmond \& C Garrett. 2005. Stratified tidal flow over a bump. Journal of Physical Oceanography 35: 1911-1927.

Joyce T. 1989. On in situ calibration of shipboard ADCPs. Journal of Atmospheric and Oceanic Technology 6: 169172.

Li C \& J O'Donnell. 1997. Tidally driven residual circulation in shallow estuaries with lateral depth variation. Journal of Geophysical Research 102 (C13): 27,915-27,929.

Lwiza KMM, DG Bowers \& JH Simpson. 1991. Residual and tidal flow at a tidal mixing front in the North Sea. Continental Shelf Research 11(11): 1379-1395.

Park MJ \& DP Wang. 1994. Tidal vorticity over isolated topographic features. Continental Shelf Research 14: 15831599.

Robinson IS. 1981. Tidal vorticity and residual circulation. Deep-Sea Research 28A: 195-212.

Tee K \& P Smith. 1993. Topographic upwelling off southwest Nova Scotia. Journal of Physical Oceanography 23: 17031726.

Valle-Levinson A \& LP Atkinson. 1999. Spatial gradients in the flow over an estuarine channel. Estuaries 22(2A): 179193.

Recibido el 16 de octubre de 2008 y aceptado el 17 de noviembre de 2008 